\title{
ZAŠTITNI RADOVI NA LOKALITETU CRKVE SV. FRANJE U SENJU
}

\author{
Blaženka Ljubović \\ Gradski muzej Senj \\ Milana Ogrizovića 5 \\ HR 53270 SENJ \\ gradski.muzej.senj@gs.t-com.hr
}

UDK: 902.2(497.5 Senj)

903.4(497.5Senj)

Stručni članak

Ur.: 2018-9-24

U Programu Ministarstva kulture Republike Hrvatske za 2017. godinu župi Uznesenja Blažene Djevice Marije u Senju dodijeljena su financijska sredstva za zaštitu lokaliteta nekadašnje crkve sv. Franje u Senju. Na temelju prethodnoga odobrenja Ministarstva kulture, Konzervatorskoga odjela u Gospiću, Gradski muzej Senj proveo je arheološki nadzor i zaštitna arheološka istraživanja nad početnim radovima zaštite - čišćenja lokaliteta nekadašnje crkve sv. Franje u Senju (I. etapa). Crkva se nalazi unutar međa kulturno-povijesne cjeline grada Senja - kulturnoga dobra upisanoga u Registar kulturnih dobara RH pod brojem Z-4186. Rješenjem Ministarstva kulture Konzervatorskoga odjela u Gospiću izdanom 14. rujna 2017. godine Odjel je dao uvjete za izvođenje zaštitnih arheoloških istraživanja - arheološkog nadzora nad radovima na zaštiti lokaliteta i njegovom početnom arheološkom čišćenju. Rješenjem je određeno da arheološko nadziranje - i po potrebi arheološko istraživanje - vrši Gradski muzej Senj, odnosno prof. Blaženka Ljubović, ravnateljica Muzeja. Početni radovi na etapnomu uređenju lokaliteta trajali su od rujna do studenoga 2017. godine.

Predmet su ovoga rada radovi na zaštiti lokaliteta nekadašnje crkve Sv. Franje u Senju i njegova početna arheološka čišćenja. Arheološki nadzor nad radovima čišćenja proveden je svrhu prikupljanja svih bitnih informacija o kulturnim slojevima i arheološkim nalazima na lokalitetu. Ovo etapno čišćenje, uz arheološki nadzor, provedeno je s ciljem utvrđivanja gabarita crkve i zaštite grobova unutar crkve od daljnjeg urušavanja i devastacije.

Ključne riječi: zaštitna arheološka istraživanja, nadzor, crkva Svetog Franje, spomenik kulture, arheološki nalazi

\section{Uvod}

Crkva sv. Franje svojom arhitekturom i inventarom bila je dragocjen spomenik kulture grada Senja velike povijesne i kulturno-umjetničke vrijednosti. $\mathrm{Tu}$ vrijednost posebno su činile nadgrobne ploče s obiteljskim grbovima i posvetnim natpisima pokojnika, umjetnički izrađene u stilu gotike, renesanse 
i baroka. Ploče su prekrivale grobove uglednih senjskih građana, patricija i redovnika iz crkve i samostana sv. Franje. Među njima posebno mjesto zauzimaju znameniti i proslavljeni senjski uskoci, odnosno uskočki knezovi, kapetani, vojvode i nadvojvode koji su u crkvi pokapani tijekom 16., 17. i 18. stoljeća.

Od samoga početka crkva je određena da bude njihovo posljednje počivalište, zbog čega je s pravom prozvana panteonom senjskih uskoka. Nažalost, Crkva je srušena 1943. kada je stradao i veliki dio njezina spomeničkoga inventara (kameni oltari, reljefi, skulpture svetaca...) unutar kojeg i nadgrobne ploče senjskih uskoka i ostalih odličnika.

Nadgrobne ploče iz crkve epigrafički su spomenici - iznimni umjetnički radovi s uklesanim grbovima i natpisima, izrađeni od bijelog i sivog vapnenca, dok je dio ostalog crkvenoga inventara bio izrađen od mramora.

Iako je crkva izgrađena sredinom 16. stoljeća, bila je skladno uklopljena u srednjovjekovni ambijent i raster gradskih ulica. Danas je od Crkve ostao sačuvan samo toranj koji je obnovljen 90-ih godina 20. stoljeća.

Najvrjednija sačuvana dokumentacija o izgledu Crkve, njezinom tlocrtu i prostoru arhitektonski je snimak tadašnjeg voditelja radova preuređenja vodovoda u Senju, inženjera Vjekoslava Horačeka iz 1894. godine (Sl. 1). Snimci tlocrta, presjeka i glavnoga pročelja objavljeni su u časopisu Viesti društva inžinira i arhitekata, dok popratni tekst daje Josip Chvala pod naslovom Crkva sv. Franje u Senju ${ }^{1}$.

Prema dostupnoj literaturi i grafičkoj dokumentaciji pratimo povijest crkve i samostana te njezinu obnovu i dogradnju. Na samostanskom objektu u prizemlju sačuvan je kameni dovratnik gotičke profilacije s natpisom: 1693. O. A. M. D. G., koji možda govori o nadogradnji dva kata samostana ili možda o nekom njegovom proširenju. ${ }^{2} \mathrm{U}$ crkvi su se tijekom povijesti događala preuređenja i dogradnje, npr. uz rozetu na pročelju probijena su dva prozora, a pred portalom crkve izgrađeno je stepenište.

Najveće promjene u crkvi dogodile su se 1888. godine prilikom restauriranja interijera kada je upravitelj sjemeništa, kanonik dr. Gaetan Bedini zbog njihove zaštite i očuvanja dao dignuti sve nadgrobne ploče s poda crkve i ugraditi ih $u$ zidove svetišta, srednje lađe i ispod kora. ${ }^{3}$ Tada su u unutrašnjosti crkve izvršsene još neke arhitektonske promjene. Nažalost, o toj restauraciji i preuređenju crkve sv. Franje nisu sačuvani zapisnik, tehnička ili ina dokumentacija. Velik propust učinjen je što prije podizanja s poda ploče nisu bile dokumentirane, tako da se ne

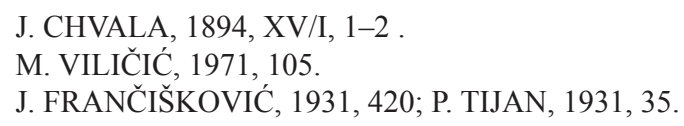




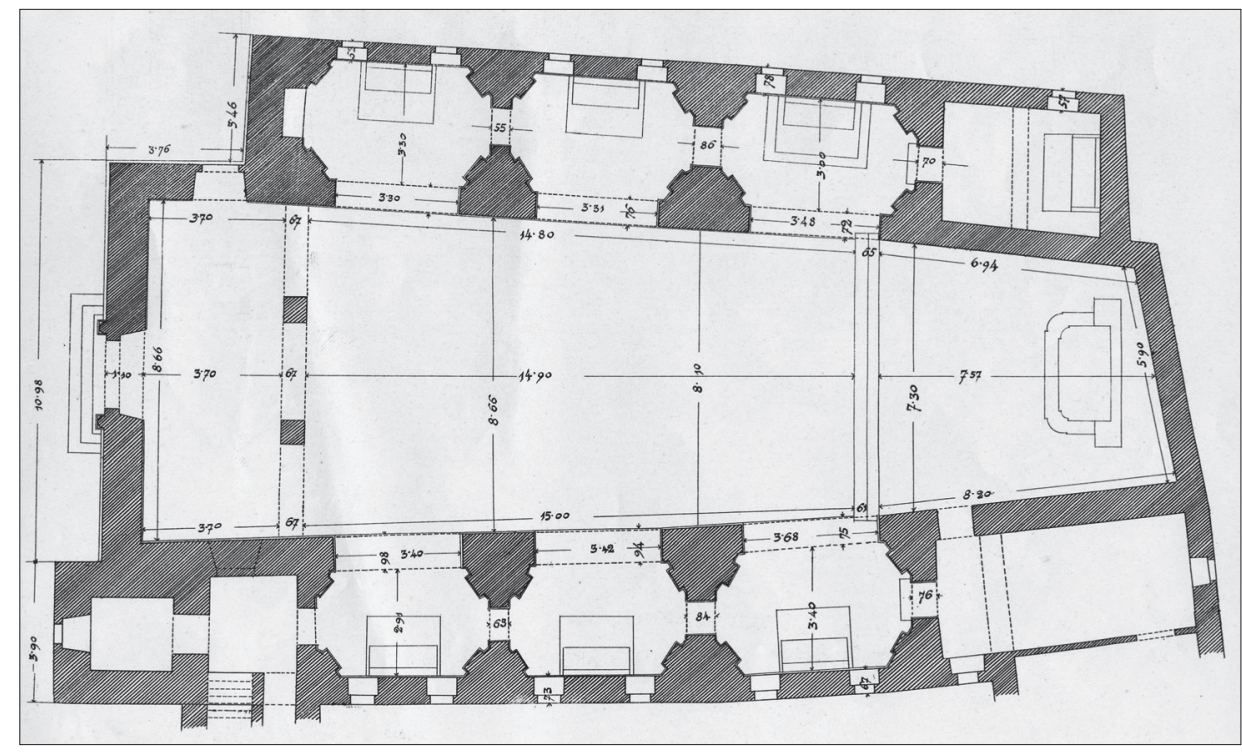

Sl. 1. Tlocrt crkve sv. Franje u Senju - arhitektonski snimak iz 1894. godine, Viesti društva inžinira i arhitekata u Zagrebu, sv. I. god. XV.

zna kojim su redom bile poredane na podu (in situ) i ne zna se i pitanje je što se od grobnoga inventara nalazilo u grobovima uz pokojnike. Posebno je to bitno jer je prema Valvasorovu opisu Senja ${ }^{4}$ iz 1689. godine poznato da su uskoci prema starom običaju bili pokopani sa svojim oružjem i pripadajućim znakovljem ili dijelovima nošnje. Stoga se pretpostavlja da je u grobovima moglo biti priloga koji bi bili značajni za senjsku povijest, na što odgovor možda mogu dati buduća arheološka istraživanja. Vrijedno je spomena za buduća istraživanja, a vezano za arhitektonski izgled i unutarnje uređenje te sadržaj crkve da su sačuvani njezini opisi prije restauracije 1888. godine, kao i prije rušenja 1943. godine u radovima poznatih autora koji su se bavili istraživanjem crkve i njezine povijesti, kao što su Ivan Kukuljević Sakcinski ${ }^{5}$, Mile Magdić6 ${ }^{6}$ Josip Frančišković ${ }^{7}$ i Pavao Tijan ${ }^{8}$, a kasnije i mnogi drugi ${ }^{9}$.

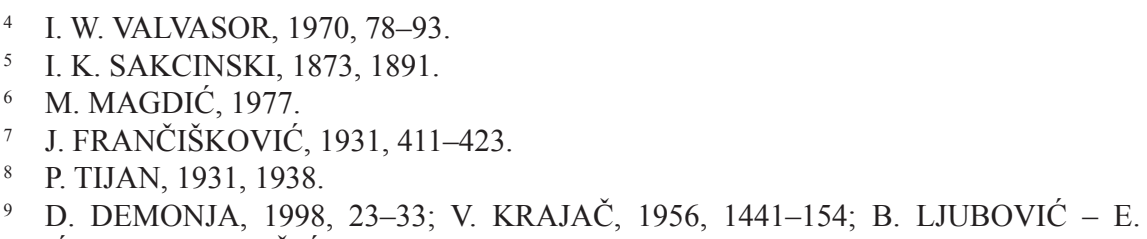



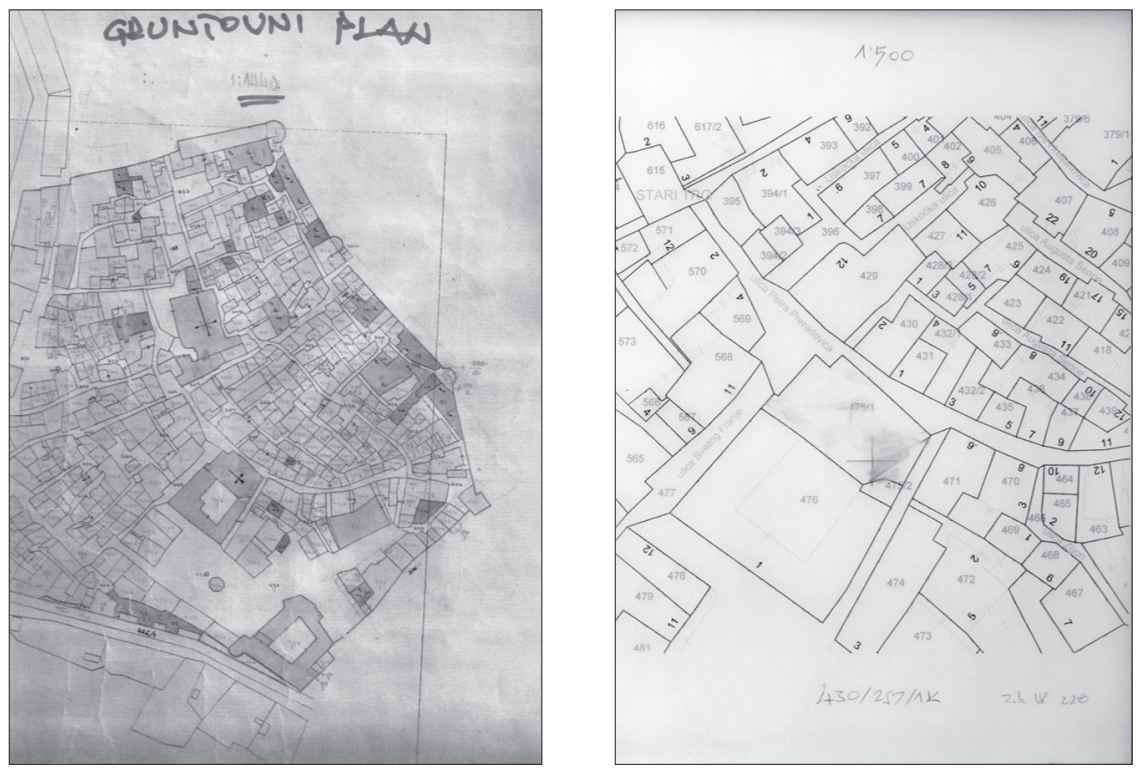

Sl. 2. (a i b). Gruntovni plan crkve Svetog Franje u Senju

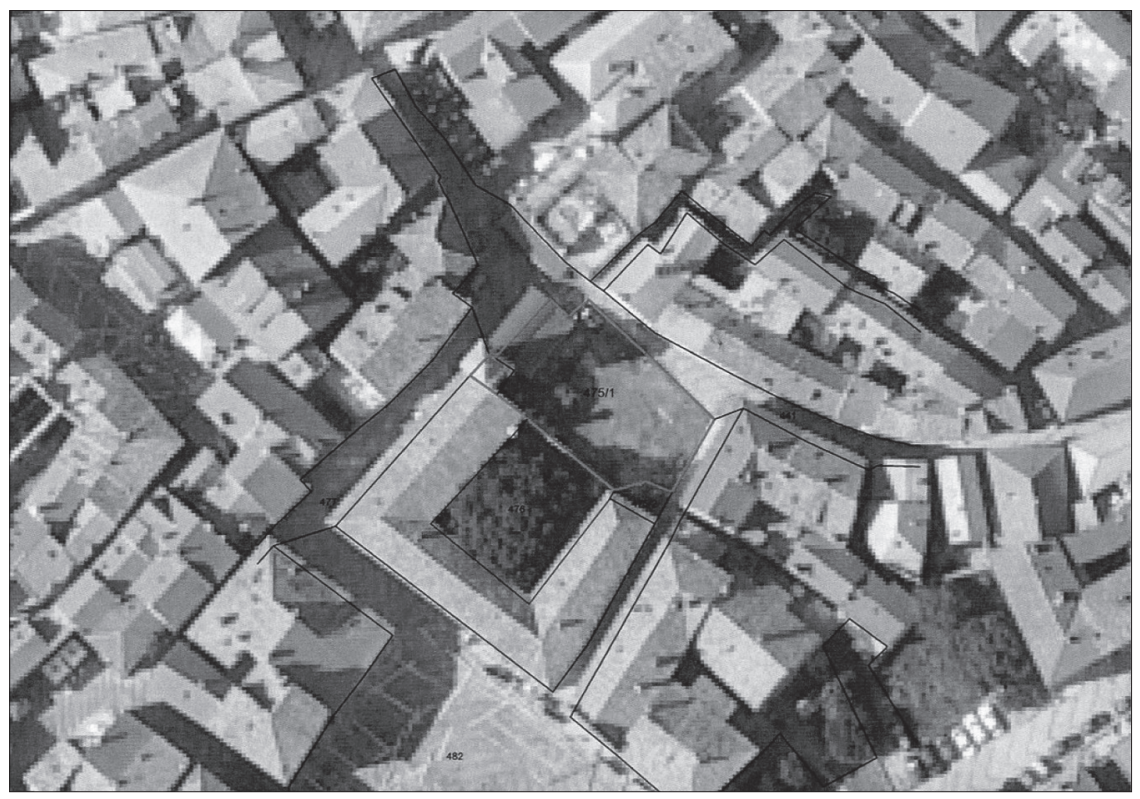

Sl. 3. Geodetski snimak temelja crkve svetog Franje na katastarskoj čestici 475/1 u k.o. Senj 


\section{Povijesni podaci o crkvi sv. Franje u Senju}

1558. Ivan Lenković u Senju je sagradio crkvu sv. Franje koja je srušena 1943. godine u Drugom svjetskom ratu ${ }^{10}$.

Oblik-temelje crkve i samostana možemo pronaći ucrtane na gruntovnom planu i geodetskom snimku Senja i na planovima Senja iz 18. i 19. stoljeća, dok tlocrte i presjeke te pročelje možemo naći na arhitektonskim snimcima Senja i u dokumentima, fotografijama i vedutama grada Senja (Sl. 2a-b, S1. 3-4).

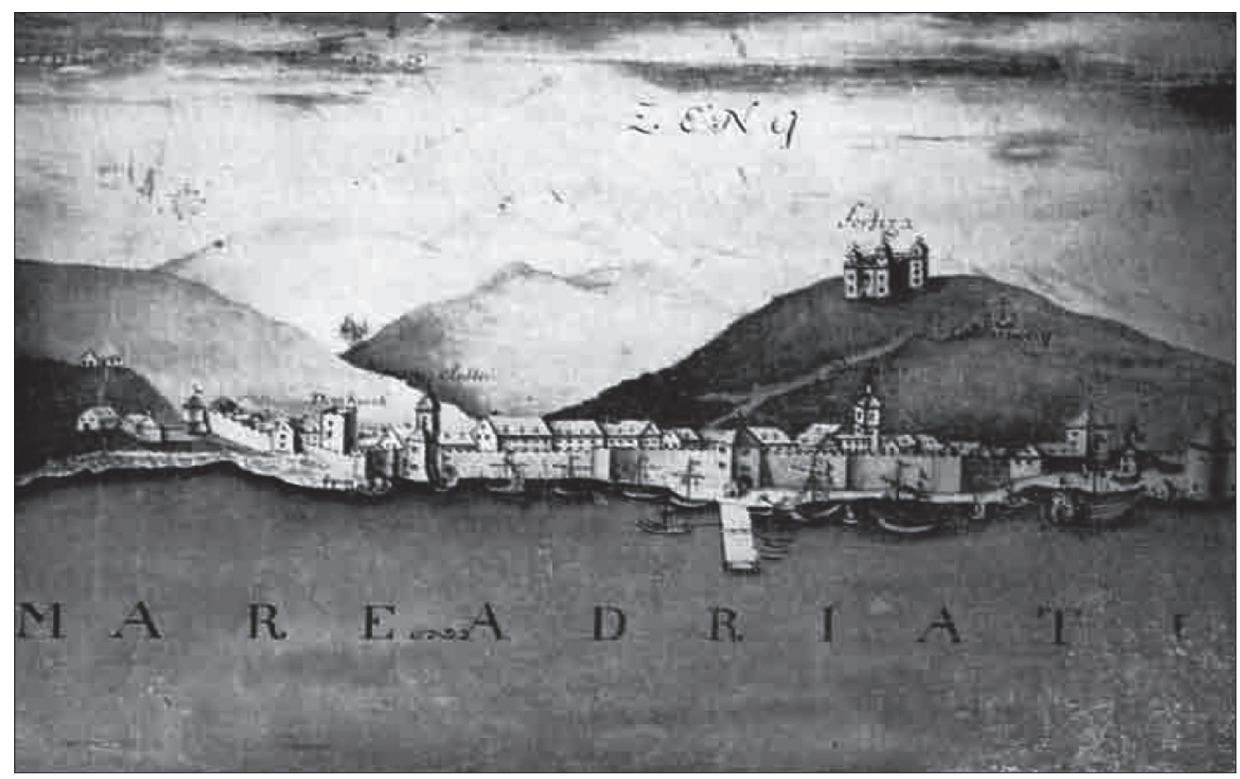

Sl. 4. Franjevačka crkva i samostan ucrtani su na planu Senja iz 1749. godine

Crkva je ucrtana na planovima Senja iz 1749., 1763. i 1779., dok je na planovima iz 1785. i 1788. posebno označen toranj, a u legendi je upisano: $k$-Franciscaner Closter und Kirche. Na planu grada iz 1779. ucrtan je blok crkve i samostana koji sliči suvremenom urbanističkom snimku grada, a konture crkve sv. Franje na tom planu odgovaraju arhitektonskom snimku ing. Vjekoslava Horačeka iz god. 1894. uz koji je, uz opis i glavne mjere crkve, izradio njezin tlocrt te uzdužni i poprečni presjek, kao i glavno pročelje.

10 A. GLAVIČIĆ, 1970, 217-223; A. GLAVIČIĆ, 1983/1984, 352; A. GLAVIČIĆ, 1992, $83-85$. 
Kad je riječ o dimenzijama crkve, vrijedan je podatak u radu Mile Magdića Topografija i povijest grada Senja, 1877., str. 19, gdje piše: crkva sv. Franje imade poput stolne crkve tri ladje. Srednja ladja je 8,50, a svaka pobočna 4 metra široka. Ciela crkva dugačka je 29,70, a široka 16,50 metara. ${ }^{11}$

Od rušenja crkve do danas bilo je više inicijativa za uređenjem njezina prostora $^{12}$. Nažalost, nijedna od predloženih inicijativa nije provedena u djelo, već je prostor crkve do naših dana ostao zapušten i nedefiniran. Rješenje je otežavalo pitanje nastaviti kontinuitet sakralnog prostora ili je moguća njegova prenamjena. Stoga je pred Crkvom i Gradom danas veoma odgovoran zadatak i pitanje kako pronaći najbolje moguće i konačno rješenje za prostor nekadašnje franjevačke crkve, ali i potrebna financijska sredstva jer to ovaj sakralni lokalitet na kojem se prije rušenja nalazila ova crkva, ponos grada Senja, svakako zaslužuje.

To pitanje nametnulo se i nakon provedene inventarizacije (1997. godine), sačuvane spomeničke građe iz razrušene crkve sv. Franje ${ }^{13}$. Danas je glavnina te građe pohranjena u Sakralnoj baštini i njezinu dvorištu, dok se manji dio nalazi na tvrđavi Nehaj i u Gradskom muzeju Senj. ${ }^{14}$ Kada se zna s kojom se spomeničkom građom raspolaže, velika je šteta i nedopustivo je da ona i dalje propada, a da lokalitet na kojem se nalazila crkva ostaje zapušten i devastiran.

Usporedno s etapnim uređenjem prostora crkve potrebno je postupno pripremati, tj. restaurirati inventarizirane nadgrobne ploče kako bi bile spremne za postavljanje na lokalitetu nekadašnje crkve kada se za to stvore uvjeti. Na taj način ploče bi se konačno zaštitile i prezentirale javnosti, a prostor crkve oplemenio do njegova konačna i cjelovita arhitektonskoga rješenja.

Namjena prostora razrušene crkve sv. Franje u budućnosti veoma je bitna, posebno ako se zna kada i zašto je crkva podignuta, što je ona značila i što još uvijek znači za povijest grada Senja. U prilog tome govori i veliki interes brojnih znanstvenika za njezinu povijest i arhitekturu.

Međutim, dok se ne postigne i pronađe konačno arhitektonsko rješenje za ovaj sakralni prostor, bilo je potrebno pristupiti radovima koji su provedeni od rujna do studenog 2017. godine u cilju zaštite lokaliteta od daljnje devastacije i neprimjerenoga korištenja.

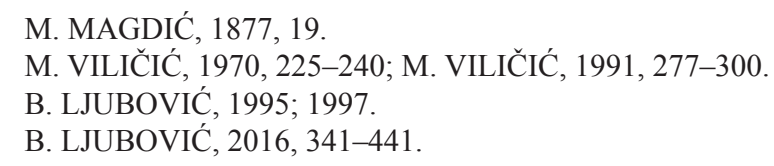




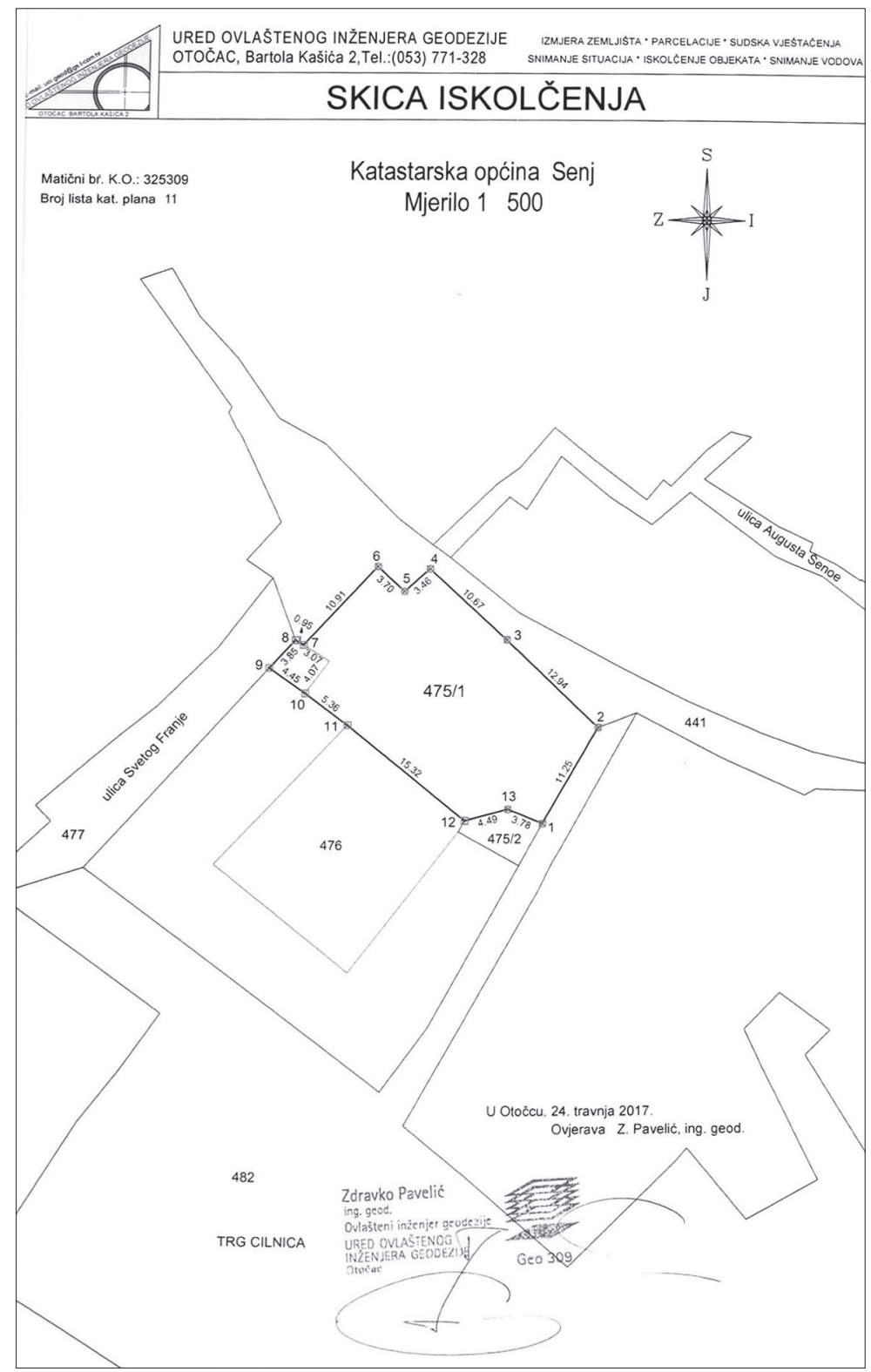

Sl. 5. Crkva sv. Franje - geodetske izmjere - skica iskolčenja s geodetskim markacijama točaka crkvenog perimetra ${ }^{15}$

15 Z. PAVELIĆ, 2017. 


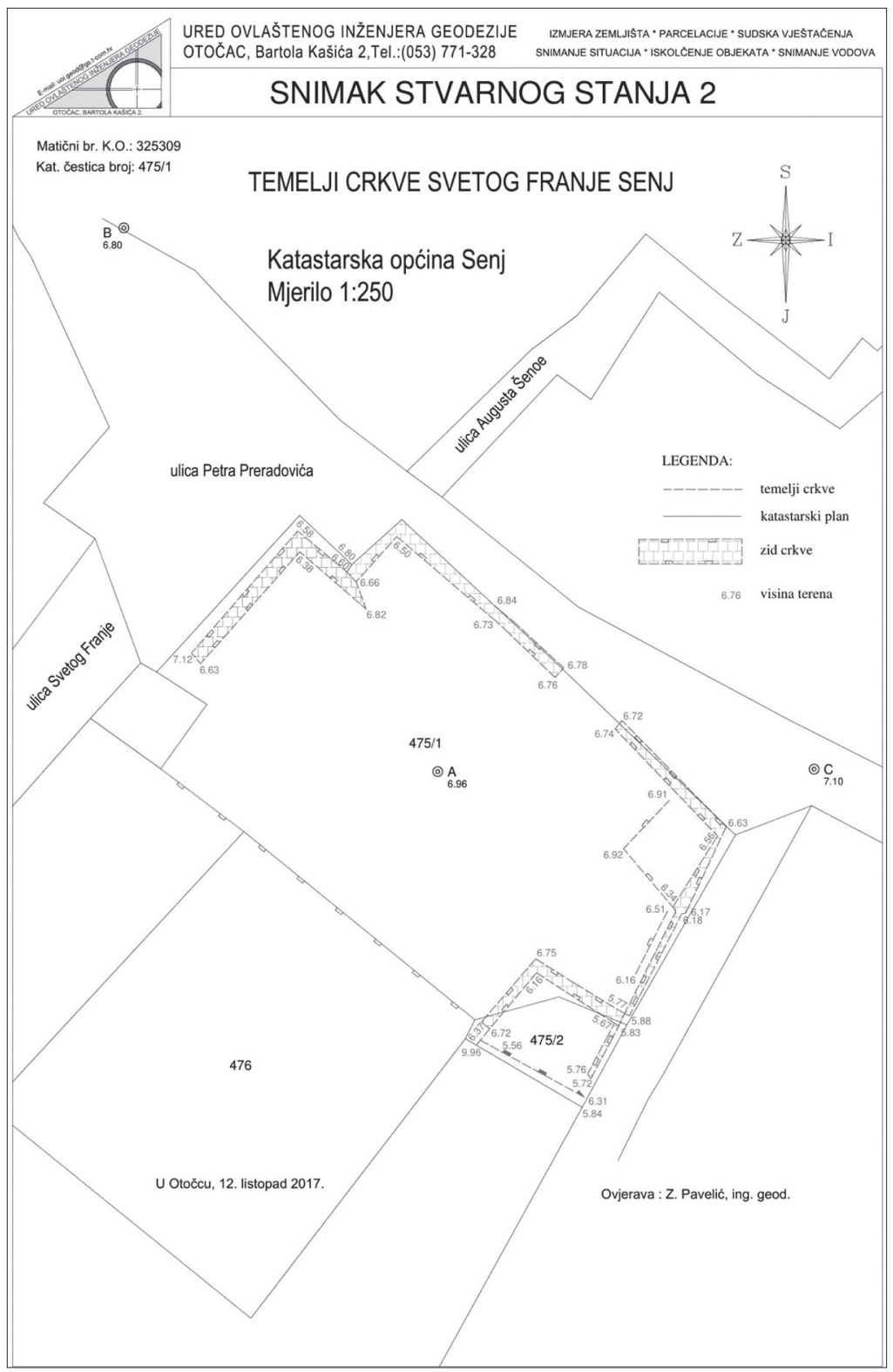

Sl. 6. Katastarski plan crkve sv. Franje u Senju s ucrtanim otkopanim temeljima i pripadajućim dimenzijama otkopa ${ }^{16}$

16 Z. PAVELIĆ, 2017. 


\section{Arheološki nadzor i čišćenje lokaliteta - nalazi}

U sklopu I. etape uređenja lokaliteta izvedeno je geodetsko snimanje prostora nekadašnje crkve sv. Franje i njegovo čišćenje uz arheološki nadzor (S1. 27-39). Geodetskim snimanjem utvrđene su točne uglovne točke crkvenog perimetra s profesionalnim geodetskim markacijama točaka (S1. 5). Na taj način utvrđene su linije rasprostiranja vanjskog ruba srušene arhitekture. To je veoma bitno s obzirom na stanje očuvanih temelja in situ, koji su dijelom devastirani dosadašnjim uređenjem gradskih ulica koje okružuju lokaciju crkve, a iste su javno dobro grada Senja.

Nakon geodetske izmjere pristupilo se čišćenju unutarnjega crkvenog prostora od samoniklog zelenila i naslaga humusa pomiješanoga s raznim otpadnim materijalom. Osim toga, trebalo je ukloniti recentne armirano-betonske stope stupova koje su ostale na prostoru crkve od ranije postavljenih ogradnih stupova, a također i druge betonske elemente koji su također služili za potrebe ranijih ograđivanja i zaštite prostora.

Kako bi se utvrdili i zaštitili ostaci zidova crkve, uz stalni arheološki nadzor, pristupilo se ručnom uklanjanju površinskih naslaga recentnoga materijala. Dio zida nije bio vidljiv zbog naslaga zemlje i raslinja niti sačuvan iznad razine poda crkve, stoga je trebalo pažljivo skidati slojeve zatečenoga materijala da se ne bi oštetili kulturni slojevi.

U slojevima profila otkopanih zidova crkve utvrđen je konglomerat recentnoga nasipa sastavljenoga od raznoga otpada, naslaga pijeska i zemlje pomiješane s kamenjem. Ove naslage raznoga materijala uglavnom su bile bez arheoloških nalaza.

Na temelju pregleda iskopa moglo se zaključiti da je dio materijala nastao i ispremještan je ranijim građevinskim radovima koji su vršeni na platou crkve, kao i ranijim uređenjem ulica uz graničnu liniju crkve. Tom su prilikom devastirani i zidovi temelja lijeve lađe crkve i svetišta koji su dijelom razbijeni i gube svoju liniju jer je pločnik ulice nalegao na dio zidova crkve.

$\mathrm{Na}$ dijelu terena uz temeljne zidove pročelja crkve, također lijeve lađe i svetišta, gdje su očekivani nalazi, pažljivo su skidani recentni slojevi nasipa. Iskop je detaljno pregledavan i tom prilikom su uz otkopane tlocrtne arhitektonske ostatke crkve pronađeni i razni profilirani ulomci od kojih neki pripadaju nadgrobnim pločama.

Uz ulomke nadgrobnih ploča i ostalog inventara crkve pronađeni su i ostaci ljudskih kostiju, željezni čavli i klinovi (Sl. 9-22). Na dijelu platoa crkve također su utvrđene velike količine recentnoga građevinskog materijala - šute, 
pomiješanoga $\mathrm{s}$ krovnom opekom i kvadrima obrađenog kamena, dijelova arhitekture od kojih je bila izgrađena crkva.

U ovoj etapi zidovi crkve su otkopani i očišćeni na dubini od oko 50 $\mathrm{cm}$ te je utvrđena širina koja varira od 50 do $80 \mathrm{~cm}$. Zidovi su solidno građeni četvrtastim priklesanim kamenom različitih veličina.

Nakon čišćenja lokaliteta areal crkve s otkopanim temeljima i zidovima geodetski je snimljen s naznačenim pripadajućim dimenzijama otkopa (Sl. 6-7). Nakon ovih radova otkopani i očišćeni temelji i zidovi crkve bili su spremni za daljnju obradu, tj. za rekonstrukciju, dopunu zidne mase i konzervaciju.

Pokretni arheološki nalazi trenutačno su pohranjeni u Gradskom muzeju Senj te će biti predani župi Uznesenja Marijina Senj.

U sklopu ovih radova, a u cilju privremene zaštite lokaliteta, tj. do sljedeće etape i osiguranja novih financijskih sredstava za nastavak radova, bilo je potrebno postaviti privremenu čeličnu zaštitnu ogradu prema utvrđenim linijama vanjskog ruba crkvenog perimetra, koji je određen geodetskom izmjerom parcele te otkopanim i očišćenim temeljima crkve (Sl. 30).

Ograđivanje prostora crkve izvršeno je svakako i s ciljem osiguranja uvjeta za planirane daljnje arheološke radove i istraživanje unutrašnjosti crkve jer se ispod poda trobrodne crkve nalaze grobovi pokojnika koje treba istražiti. Postavljanje ograde također je bilo potrebno i za čuvanje crkvenog posjeda od stihijskog devastiranja i uglavnom neprimjerenoga i neovlaštenoga dosadašnjeg korištenja.

U sljedećim etapama planira se unutrašnji prostor nekadašnje crkve u potpunosti očistiti do izvorne kote nekadašnjeg poda kako bi se arheološki istražili kulturni slojevi na čitavoj površini, uključujući i grobove unutar crkvenog prostora koji su predmet budućih istraživanja.

Značajno je napomenuti da će istraživanja pomoći u konačnom rješenju unutarnjeg areala - platoa crkve koji će se javno koristiti na temelju izrade projektne arhitektonsko-tehničke dokumentacije. Pri obnovi će se dijelom koristiti izvorni materijal od srušene crkve, preostali priklesani kamen, tj. kameni kvadri i nadgrobne ploče koje su sortirane i spremljene za ponovnu ugradnju u zidove crkve.

\section{Zaključak}

Arheološki nadzor nad čišćenjem arhitektonskih ostataka crkve proveden je prema skici iskolčenja kako bi se uz čišćenje unutarnjega i vanjskoga lica zida, odnosno zidne mase temelja crkve na određenoj dubini i visini utvrdili i istražili njezini gabariti. 


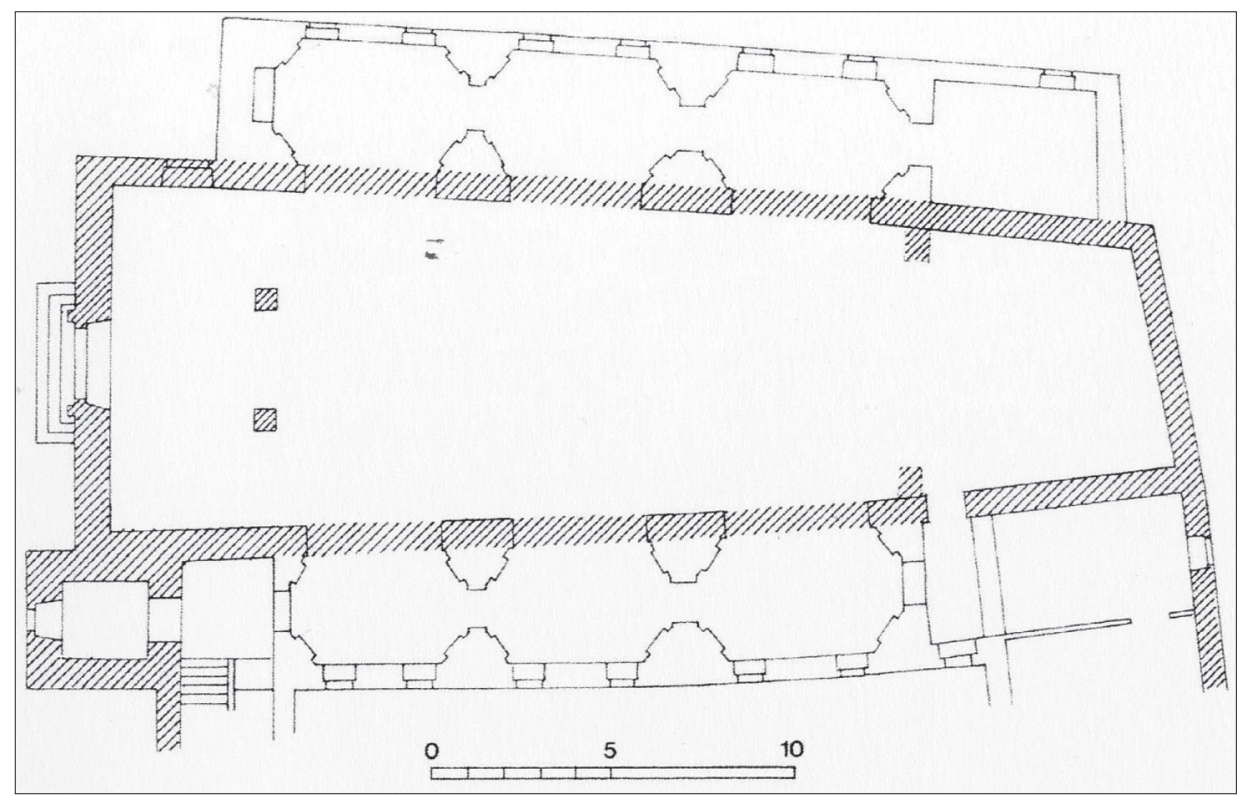

S1. 7. Tlocrt crkve sv. Franje - arhitektonski snimak iz 1894. godine

Nadamo se da će početni arheološki radovi na etapnom uređenju i zaštiti lokaliteta nekadašnje crkve sv. Franje u Senju konačno ubrzati odluku o revitalizaciji i namjeni sakralnog lokaliteta i pripadajućeg mu prostora. Nedopustivo je da to bude nedefiniran i zapušten prostor izložen devastaciji svake vrste, kao i njezina preostala spomenička građa koja je obrađena inventarizirana, ali i dalje ugrožena jer je neadekvatno deponirana i izložena utjecaju atmosferilija.

Dok se čeka konačno rješenje za sakralni lokalitet, prioritetne i važne aktivnosti svakako su zaštita i čišćenje, što je i provedeno u I. etapi od rujna do studenog 2017., radi zaštite sakralnog prostora u kojem se još uvijek nalaze uskočki grobovi koje treba istražiti i zaštititi od urušavanja i devastacije.

Arheološkim nadzorom nad provedenim radovima (I. etapa) na čišćenju i zaštiti lokacije nekadašnje crkve sv. Franje u Senju istraženi su i utvrđeni gabariti crkve prema katastarskom planu i arhitektonskim snimcima crkve u svrhu prikupljanja svih važnih informacija o kulturnim slojevima i arheološkim nalazima na lokalitetu.

Istraživanja su potvrdila očekivanja - otkopani su arhitektonski ostaci crkve, utvrđeno je rasprostiranje temeljnih zidova njezine srušene arhitekture, 
pronađen je zanimljiv arheološki materijal, ulomci nadgrobnih ploča, željezni čavli i klinovi, ostaci ljudskih kostiju i dijelovi srušene arhitekture - kvadri obrađenog kamena od kojeg je crkva bila izgrađena.

Pitanje eventualne buduće zaštite i prezentacije nalaza rješavat će se tijekom provođenja planiranoga etapnog istraživanja prostora nekadašnje crkve sv. Franje.

\section{Literatura}

Josip CHVALA, Crkva sv. Franje u Senju, Viesti društva inžinira i arhitekata, XV/1, Zagreb, 1894, 1-2 .

Damir DEMONJA, Prilog interpretaciji crkve Sv. Franje u Senju, Institut povijesti umjetnosti, 22, Zagreb, 1998, 23-33.

Josip FRANČIŠKOVIĆ, Crkva sv. Franje u Senju, Bogoslovska smotra, XIX, Zagreb, 1931, 411-423.

Ante GLAVIČIĆ, Informacija za obnovu tvrđave Nehaj i izgradnju uskočkog mauzoleja u gradu Senju 1972. - 1975., Senjski zbornik, 4, Senj, 1970, 205-223.

Ante GLAVIČIĆ, Njemačko bombardiranje Senja, Senjski zbornik, Senj, 1983./1984,10$11,341-354$.

Ante GLAVIČIĆ, Stara i nova groblja, grobovi na području grada Senja i šire senjske okolice (I), Senjski zbornik, 19, Senj, 1992, 81-108.

Vuk KRAJAČ, Značajni objekti, koji su ovog rata u Senju razoreni, Vijesti muzealaca, Zagreb, 1956, 144-154.

Ivan KUKULJEVIC-SAKCINSKI, Putne uspomene iz Hrvatske, Dalmacije, Arbanije, Krfa i Italije, Zagreb, 1873.

Ivan KUKULJEVIĆ-SAKCINSKI, Nadpisi sredovječni i novovjeki na crkvah i javnih $i$ privatnih sgradah u Hrvatskoj i Slavoniji, Zagreb, 1891.

Blaženka LJUBOVIĆ, Elaborat o izvršenoj inventarizaciji građe crkve sv. Franje, Senj, rujan, 1995.

Blaženka LJUBOVIĆ, Inventarizacija i zaštita građe iz razrušene crkve Sv. Franje u Senju, rukopis, 1997.

Blaženka LJUBOVIĆ - Enver LJUBOVIĆ, Grbovi i natpisi na kamenim spomenicima Senja, Senj, 1996.

Blaženka LJUBOVIĆ, Inventarizacija i zaštita građe iz razrušene crkve Sv. Franje u Senju i njezina buduća namjena, Senjski zbornik, 42-43, Senj, 2016, 341-441.

Mile MAGDIĆ, Topografija i povijest grada Senja, Senj, 1877.

Zdravko PAVELIĆ, Elaborat, skica iskolčenja perimetra crkve sv. Franje, 2017.

Zdravko PAVELIĆ, Elaborat, skica stvarnog stanja iskopanih temelja crkve sv. Franje, 2017.

Pavao TIJAN, Vodič po Senju i okolici, Senj, 1931. 
Pavao TIJAN, 50 godišnjica jedne crkvene restauracije, Uskočka crkva sv. Franje u Senju, Obzor, 1938.

Ivan Weikhard Valvasor, O Senju i Senjanima. Dometi, 3/8, Rijeka, 1970, 78-93.

Melita VILIČIĆ, Kakvu namjenu dati prostoru porušene memorijalne crkve Sv. Franje u Senju, Senjski zbornik, 4, Senj, 1970, 225-240.

Melita VILIČIĆ, Arhitektonski spomenici Senja, Rad JAZU, Knjiga 360, Zagreb, 1971.

Melita VILIČIĆ, Skice grafičkih rekonstrukcija nekih drevnih senjskih sakralnih građevina, Senjski zbornik, 18, Senj, 1991, 277-300.

\section{CONSERVATIONAL ARCHAEOLOGICAL INVESTIGATION AT THE SITE OF THE CHURCH OF ST FRANCIS IN SENJ}

\section{Summary}

In a programme of the Ministry of the Republic of Croatia from 2017, financial funds were allocated to the Parish of the Assumption of the Blessed Virgin Mary for the protection of the site of the former Church of St Francis in Senj. On the basis of the previous approval of the Ministry of Culture, of the Conservation Department in Gospić, the Senj Town Museum carried out archaeological supervision and protective investigation over the initial works of preservation the cleaning of the site of the former Church of St Francis in Senj (Stage 1). The church is located between the cultural-historical whole of the town of Senj - a cultural asset listed in the Register of Cultural Goods of the Republic of Croatia under the number of Z-4186. With a resolution of the Ministry of Culture, the Conservation Department in Gospic issued on $14^{\text {th }}$ September 2017 the Department gave the conditions for the implementation of protective archaeological investigations - the archaeological supervision over works on the protection of the site and its initial archaeological cleaning. With the resolution it was determined that the archaeological supervision - and if necessary archaeological investigation - be carried out by the Senj Town Museum, in other words, Professor Blaženka Ljubović, the director of the museum. The initial works in the preparation stage of the site lasted from September to November in 2017.The subject of this paper is the works regarding the preservation of the former Church of St Francis in Senj and its initial archaeological cleaning. The archaeological supervision of the cleaning works was carried out with the purpose of gathering all the important information about the cultural levels and archaeological finds at the site. This cleaning stage, along with the archaeological supervision, was carried out with the aim of establishing the dimensions of the church and the protection of graves within the church from further collapse and ruin.

Keywords: protection of archaeological investigation, supervision, Church of St Francis, cultural monument, archaeological finds 


\section{ARHEOLOŠKI NALAZI NA LOKALITETU NEKADAŠNJE CRKVE SV. FRANJE ${ }^{17}$}

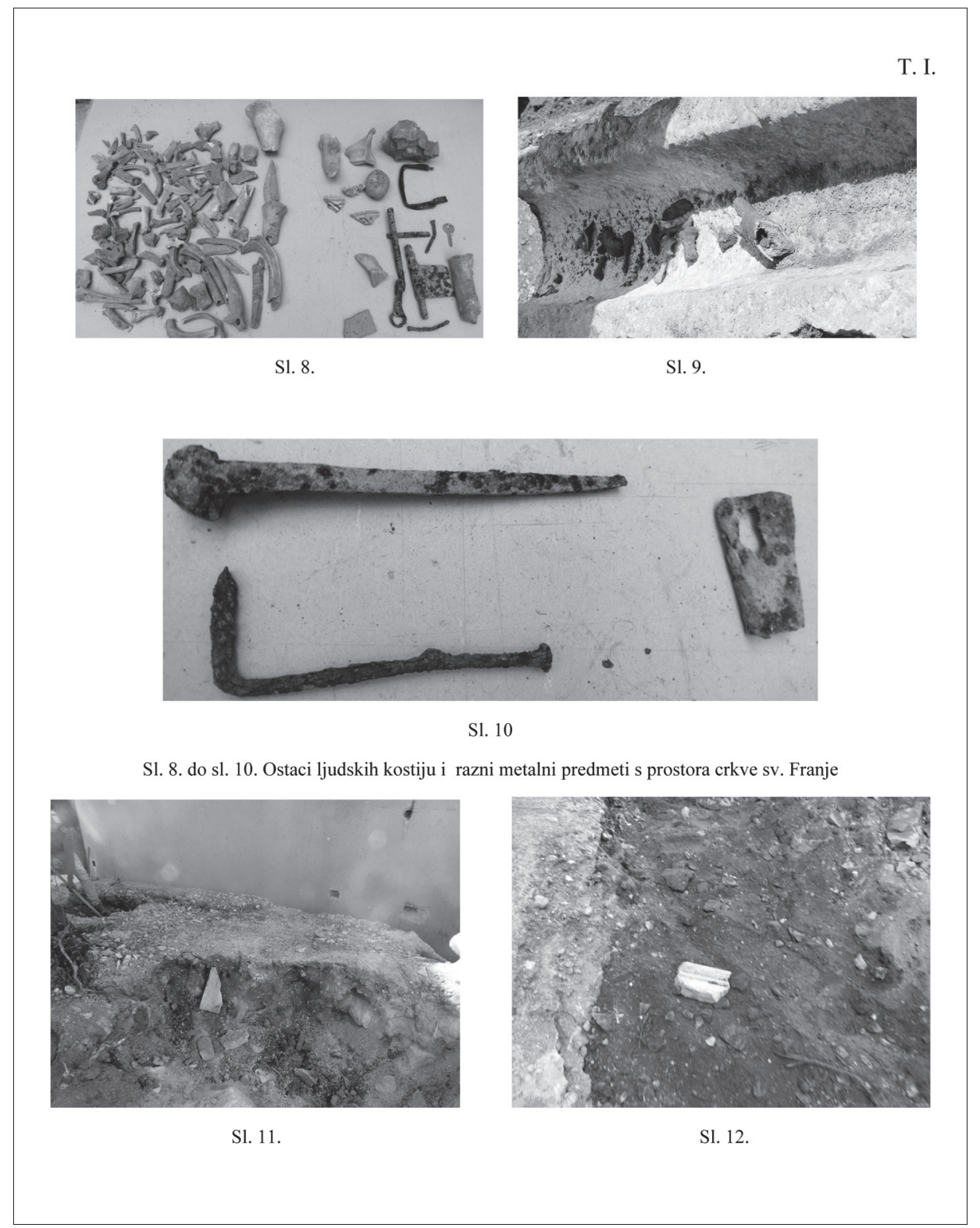

17 Fotografije iz arhive Gradskog muzeja Senj. 


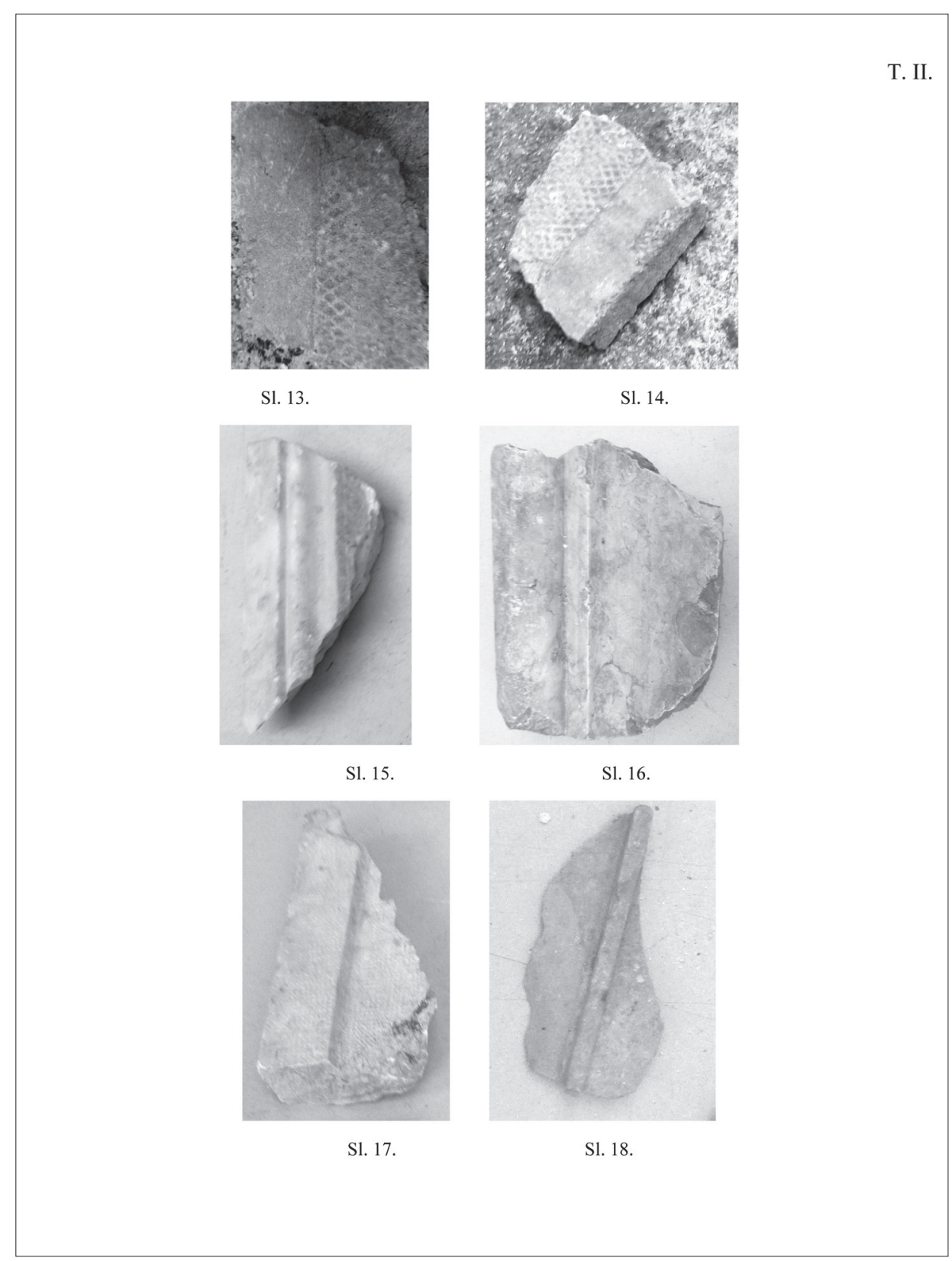




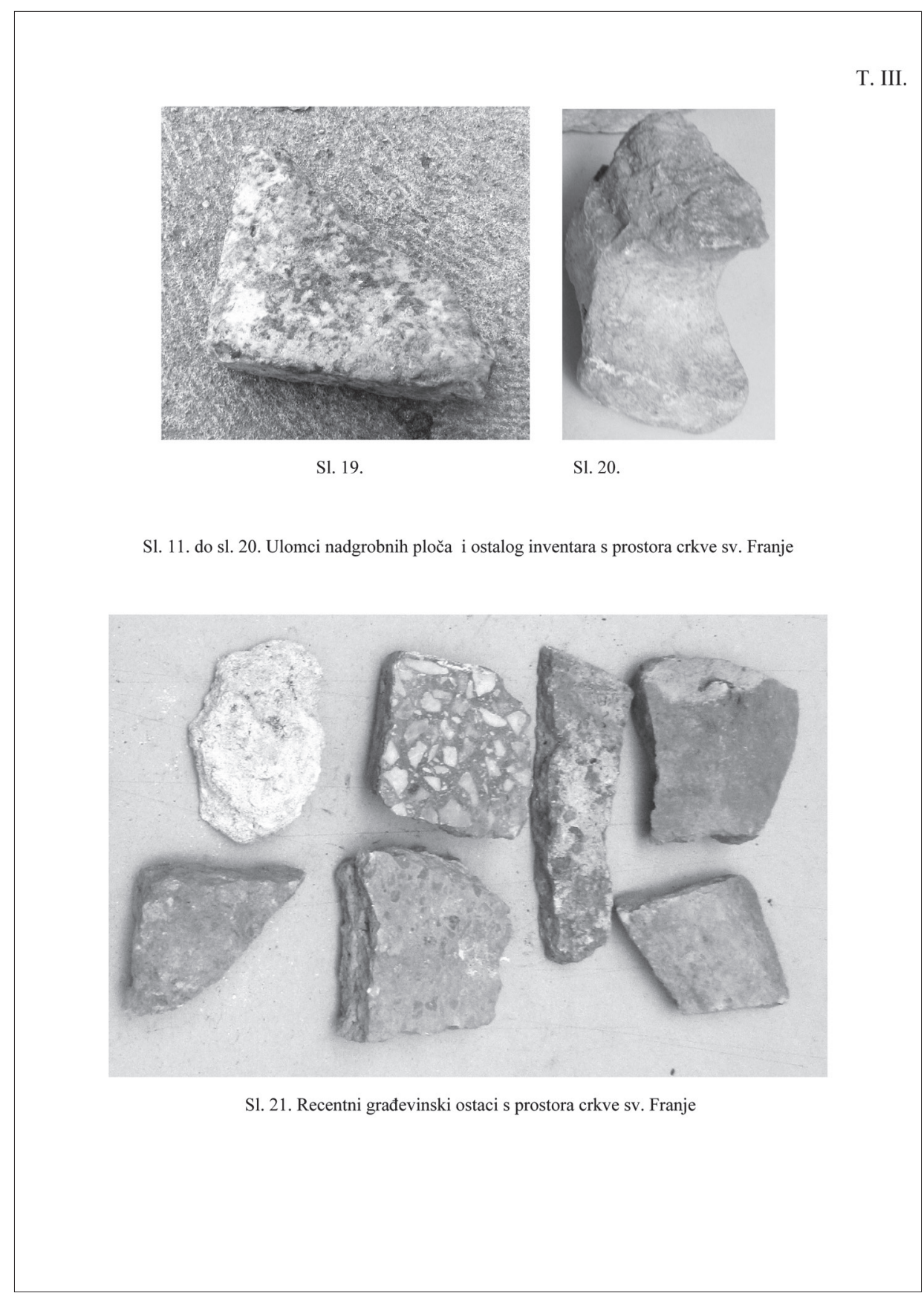




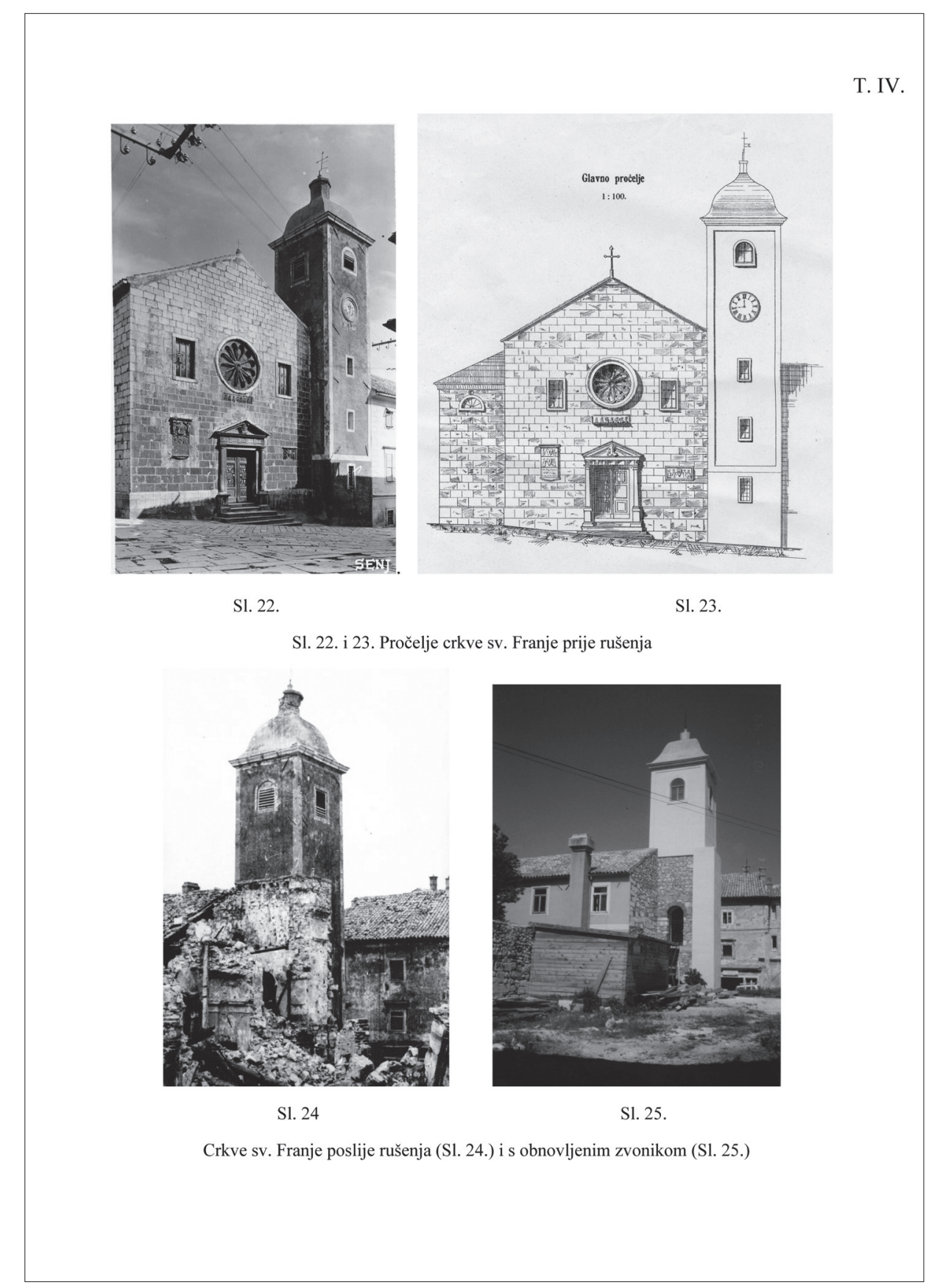




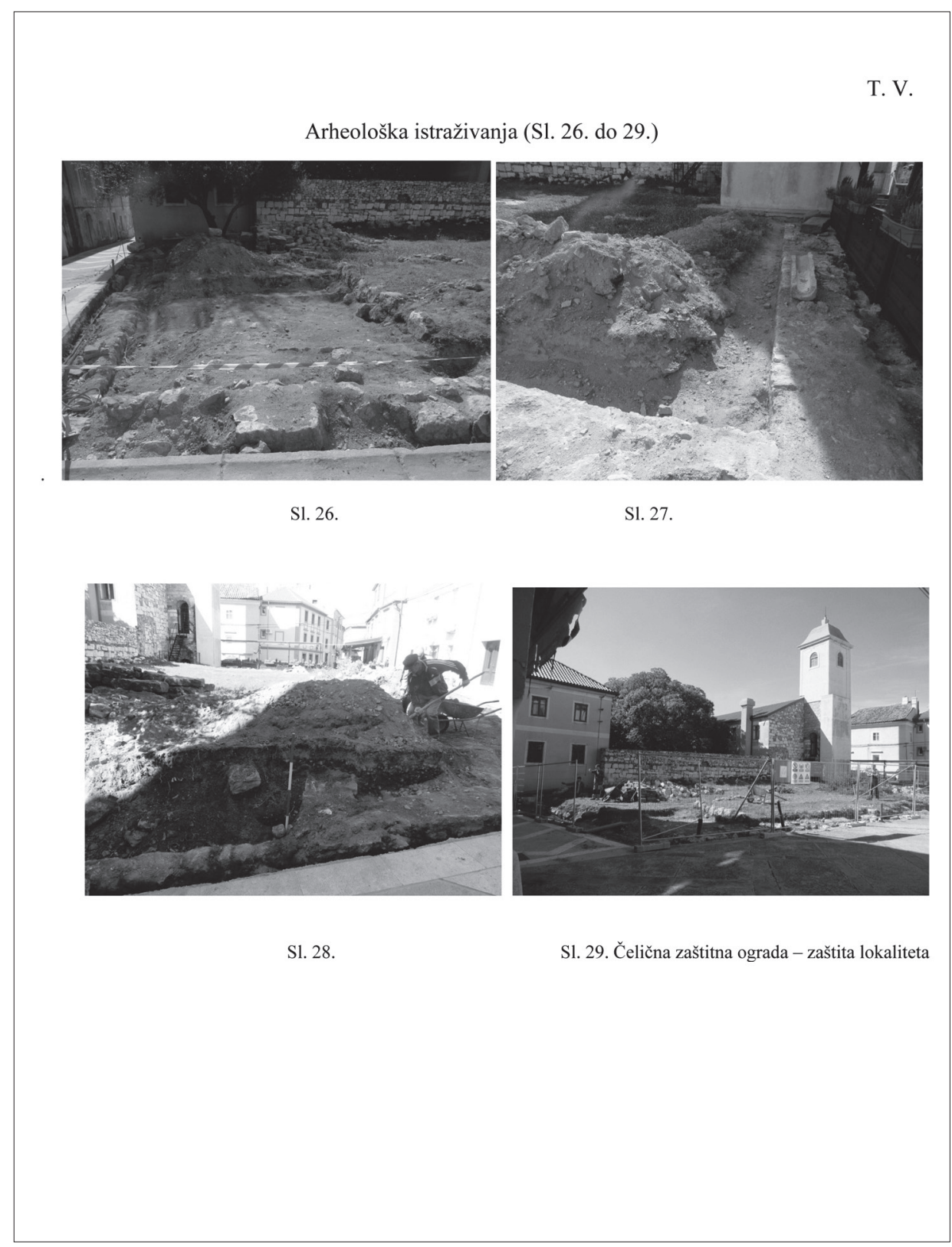

